\title{
HIGH-SPEED SOLAR WIND STREAMS DURING THE LAST SOLAR CYCLES
}

Asenovski S.

Space Research and Technology Institute-BAS, Sofia, Bulgaria

\section{ВЫСОКОСКОРОСТНЫЕ ПОТОКИ СОЛНЕЧНОГО ВЕТРА В ТЕЧЕНИЕ ПОСЛЕДНИХ СОЛНЕЧНЫХ ЦИКЛОВ}

\author{
Асеновски С. \\ ИКИТ-БАН, София, Болгария
}

\begin{abstract}
Высокоскоростные потоки солнечного ветра (High Speed Solar Wind Streams, HSS) выявлены как одна из основных причин геомагнитных бурь. После его идентификации в 1962, наше познание об этом проявлении солнечной активности стало более точным. Теперь у нас есть экспериментальные данные о параметрах солнечного ветра в течение последних четырех 11-летних циклов солнечной активности, и мы можем описать поведение HSS за относительно длительный период. Более того, кажется, что настоящий период векового иикла солнечной активности является "переходным" - от экстремально высокой солнечной активности, наблюдаемой в циклах 18-22, до сегодняшнего дня, когда мы наблюдаем чувствительно более низкую солнечную активность (цикл 24). Несколько моделей прогнозируют даже еще более низкую активность в следуюших ичклах. Имея измерения поведения HSS во время этих двух периодов (высокая и низкая солнечная активность), мы исследуем, как влияет на HSS вековая вариация солнечной активности.
\end{abstract}

DOI: 10.31725/0552-5829-2018-39-42

\section{Introduction}

High speed solar wind streams (HSS) and Coronal mass ejections (CME) are recognized as main geomagnetic storm drivers. According [1] HSS are responsible for at least $70 \%$ of geomagnetic activity at solar minimum and more than $30 \%$ at maximum. HSS are characterized with low speed, temperature and plasma density $[2,3]$. They are geoeffective at most during the sunspot declining phase [4], when the second maximum in the geomagnetic activity is observed. Considering the year of identification of HSS (1962), early investigations of the solar cycle evolution of HSS has been presented by [5, 6]. They study variations of HSS during the period 1962-1974 (covering solar cycle 20) with emphasis on the solar wind speed fluctuation, the effect of the temporal evolution of stream structure on long-term averages of the solar wind flow speed, relationship between solar wind stream structure and the interplanetary magnetic field sector polarity. The major conclusion of these studies is that during the solar minimum the most stable streams with the largest amplitude occurred. The Mariner-2, Pioneer-6, 7, Vela and IMP programs are solar wind data sources at the time of solar cycle 20. 
In this study solar cycle evolution of HSS for the cycles 21-24 as well as differences of the averaged parameters are discussed.

\section{Data and methods}

This work considers the solar wind data for the last four solar cycles. In Table 1 is presented information for Solar cycles 17-24, including the duration of the different cycles.

Table 1.

\begin{tabular}{|c|c|c|c|}
\hline Cycle & Started & Finished & Duration (years) \\
\hline Solar cycle 17 & 1933 September & 1944 February & 10.4 \\
\hline Solar cycle 18 & 1944 February & 1954 April & 10.2 \\
\hline Solar cycle 19 & 1954 April & 1964 October & 10.5 \\
\hline Solar cycle 20 & $\mathbf{1 9 6 4}$ October & 1976 June & $\mathbf{1 1 . 7}$ \\
\hline Solar cycle 21 & $\mathbf{1 9 7 6}$ June & 1986 September & $\mathbf{1 0 . 3}$ \\
\hline Solar cycle 22 & $\mathbf{1 9 8 6}$ September & $\mathbf{1 9 9 6}$ May & $\mathbf{9 . 7}$ \\
\hline Solar cycle 23 & $\mathbf{1 9 9 6}$ May & $\mathbf{2 0 0 8}$ January & $\mathbf{1 1 . 7}$ \\
\hline Solar cycle 24 & $\mathbf{2 0 0 8 ~ J a n u a r y}$ & $\mathbf{2 0 1 8}$ & $\sim 11$ \\
\hline
\end{tabular}

Several catalogues of HSS for Solar cycles 21-23 have been used to determine the time and duration of the events [7-9]. Using hourly values of the plasma parameters gathered in OMNI data base (http://omniweb.gsfc.nasa.gov/) the averaged values of the main parameters for every single event have been calculated.

312 HSS for Solar cycle 24 events have been identified using the criteria for a HSS - an increase of the solar wind velocity by at least $100 \mathrm{~km} / \mathrm{s}$ in no more than one day to at least $450 \mathrm{~km} / \mathrm{s}$ for at least five hours along with high proton temperature and low plasma density.

\section{Results}

In Fig. 1 and Fig. 2 averaged values of the HSS for solar cycles 21-23 of the maximum speed (red line), duration of the HSS (blue line) and sunspot number (black line) are presented. During the descending phase of these cycles the highest values of maximum speed and the longest duration of the HSS (8-10 days) are observed.

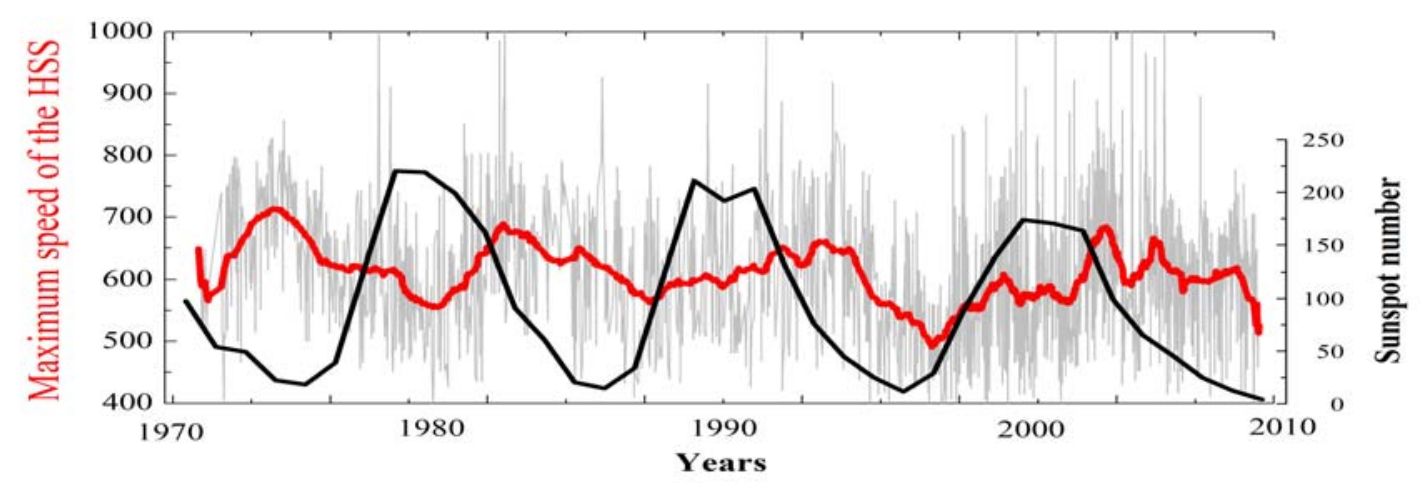

Fig. 1. Maximum speed of HSS for solar cycles 21-23. 


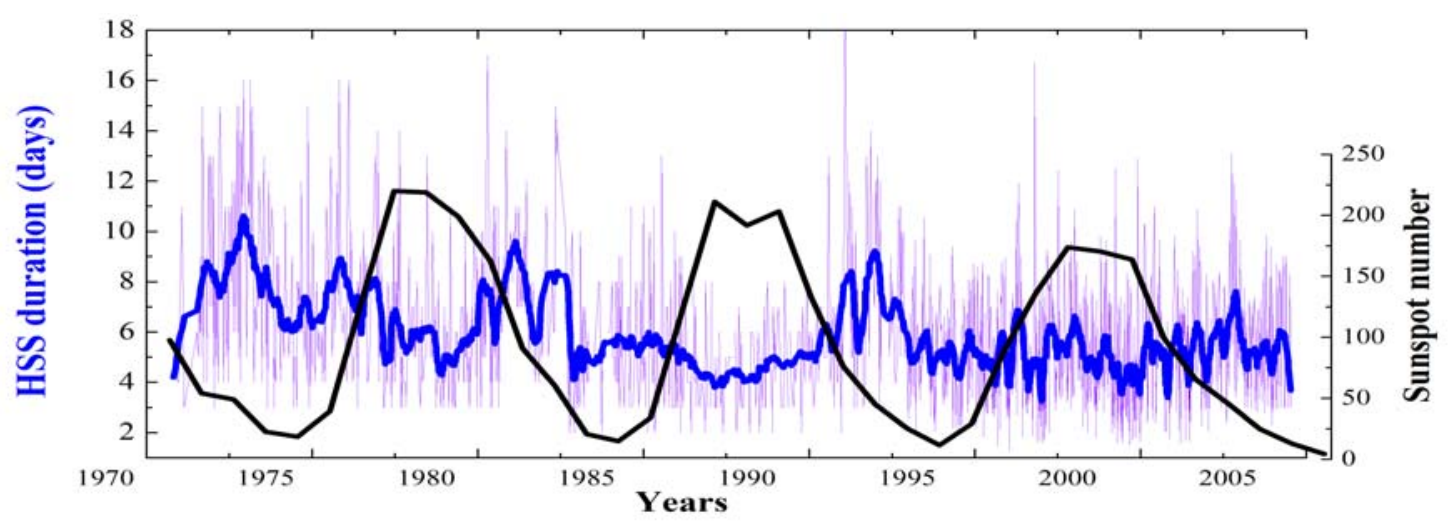

Fig. 2. Maximum speed of HSS for solar cycles 21-23.

The main results about maximum speed and counts of HSS for solar cycle 24 are presented in Fig. 3. It can be seen that there are two peaks of the number of HSS occurrence - one during the ascending phase and one at the descending phase of the solar cycle. Unlike the previous cycles, there is no such welldefined peak in the maximum speed of HSS in the current/present solar cycle.
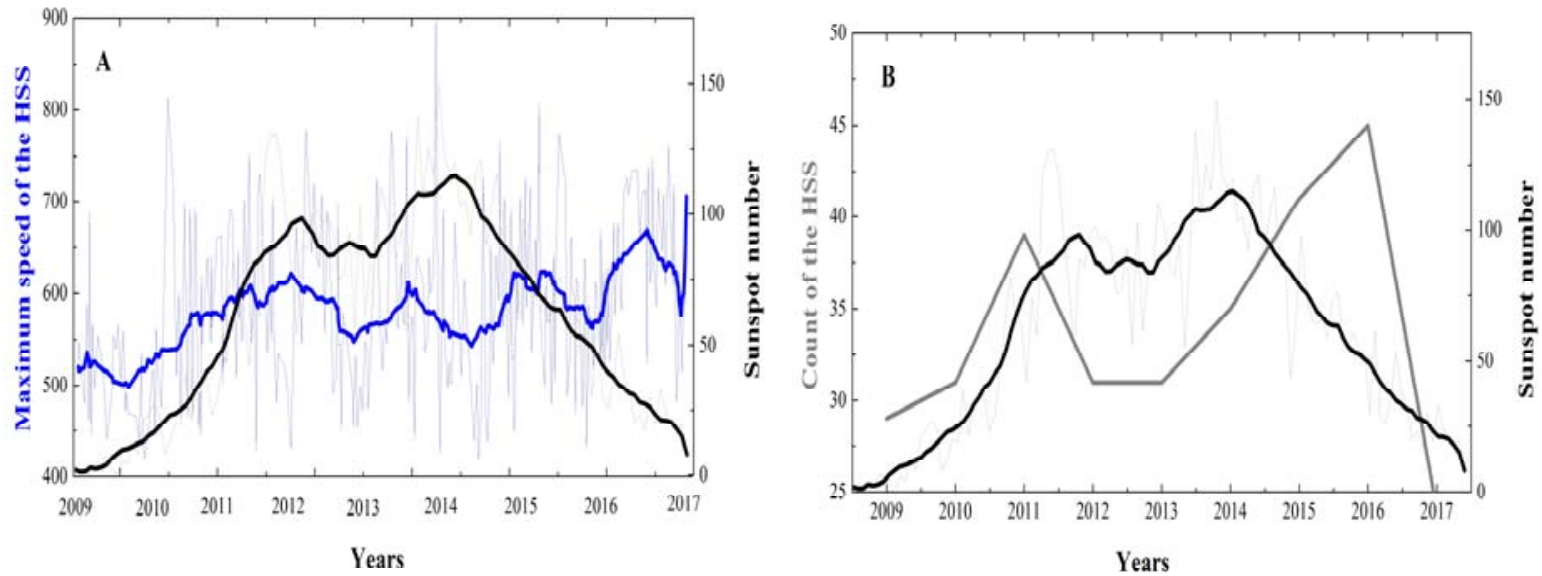

Fig. 3. Maximum speed and counts of HSS for solar cycle 24.

Table 2.

\begin{tabular}{|c|c|c|c|c|}
\hline Parameter & SC21 & SC22 & SC23 & SC24 \\
\hline Hours & 7878 & 7161 & 9811 & 8690 \\
\hline Scalar B, nT & 5.9 & 5.9 & 5.6 & 4.7 \\
\hline Bx, nT & -0.36 & 0.15 & 0.27 & -0.18 \\
\hline By, nT & 0.34 & 0.03 & -0.09 & 0.08 \\
\hline Bz, nT & 0.22 & -0.01 & -0.11 & 0.02 \\
\hline T, K & 178230 & 146090 & 205240 & 132840 \\
\hline Dens, N/c & 5.6 & 6.1 & 6.9 & 4.1 \\
\hline Speed, km/s & 512 & 508 & 463 & 518 \\
\hline Press & 2.7 & 2.8 & 2.5 & 1.9 \\
\hline
\end{tabular}

In Table 2 the averaged values of the HSS parameters for the different cycles are shown. 


\section{Conclusions}

This study considers the averages of the main HSS parameters in the last four solar cycles (21-24). The conclusion remarks are:

- The time in which Earth is under the HSS influence is more than $50 \%$ of the total time in each of the last four solar cycles.

- At SC23 the HSS influence is more than $75 \%$ of the total time.

- During the last SC24 the averaged HSS speed drops under $500 \mathrm{~km} / \mathrm{s}$ while HSS temperature increases to more than $200000 \mathrm{~K}$.

- During the descending phase of the solar cycles 21-23 the highest values of maximum HSS speed are observed.

- The duration of the HSS is the longest (8-10 days) during the descending phase of solar cycles 21-23.

- 302 HSS events have been isolated for the last $24^{\text {th }}$ solar cycle and their maximum speed was estimated.

- The profile of the maximum speed of HSS within the $24^{\text {th }}$ solar cycle is different compared to the previous solar cycles and no maximum value is observed.

- The count of the HSS is the greatest during the descending phase of the $24^{\text {th }}$ solar cycle.

\section{Acknowledgments}

This work was supported by the "Competition for financial support for projects of junior researchers - 2016" under grant DM 04/4 "Investigation of the impulsive solar activity agents throughout the 11-year solar cycle".

\section{References}

1. Richardson I.G., Cliver E.W., Cane H.V. // J. Geophys. Res., 2000, vol. 105, 18203.

2. Sheeley Jr. N.R., Harvey J.W., Feldman W.C. // Sol. Phys., 1996, vol. 49, 271.

3. Tsurutani B.T., Gonzalez W.D., Tang F., Lee Y.T. // Geophysical Research Letters, 1992, vol. 19, 1, 73.

4. Phillips J.L., Bame S.J., Feldman W.C., et al. // Science, 1995, vol. 268, 1030.

5. Bame S.J., Asbridge J.R., Feldman W.C., Gosling J.T. // Astrophys. J., 1976, vol. 207, 977.

6. Gosling J.T., Asbridge J.R., Bame S.J., Feldman W.C. // J. Geophys. Res., 1976, vol. 81, 5061.

7. Lindblad B.A., Lundstedt H.A. // Sol. Phys., 1981, vol. 74, 197.

8. Mavromichalaki H., Vassilaki A. // Sol. Phys., 1998, vol. 183, 181.

9. Xystouris G., Sigala E., Mavromichalaki H. // Sol. Phys., 2014, vol. 289, 995. 